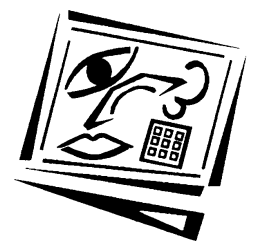

\title{
Using Conversant Media as a collaborative learning tool in teacher education
}

\author{
Myint Swe Khine and Atputhasamy Lourdusamy \\ Nanyang Technological University, Singapore
}

\begin{abstract}
Conversant Media is a server based application software enabling users to engage in collaborative discussion by attaching notes to video footage. Conversant Media was used in the module Instructional Strategies and Effective Learning at the National Institute of Education, Singapore as a way to engage students in reflective analysis of authentic classroom teaching episodes so that they will have a deeper understanding of how the theories are translated to actual practice in classroom situations. Participants were surveyed to obtain reactions to video clips, writing comments, reading comments, features of Conversant Media and overall impressions. Results indicate that students benefited from the use of the software in the delivery of this course, through improved commentary skills. Trainee teachers developed abilities to analyse teaching episodes and make quality comments reflecting an improved understanding of the teaching-learning process in classrooms.
\end{abstract}

\section{Introduction}

One of the major shifts in education under the influence of information and communication technologies is an increased tendency toward collaborative learning among students and with their teachers. Many educational institutions embark on projects which involve information sharing activities among students and teachers, regardless of time and location differences (Kearsley, 2000).

According to Jonassen, Peck and Wilson (1999), people are social creatures who like to talk with each other about topics of common interest. The number of active and interactive discourse communities has expanded in recent years due to the easy access to the telecommunication services. Lewin's (1943) prediction of the handling of human beings not as isolated individuals, but in the social setting of groups, is becoming a reality in technological society. 
Palloff and Pratt (2001) stated that collaborative learning processes help students to achieve deeper levels of knowledge generation through the creation of shared goals, shared exploration, and a shared process of meaning-making. The common features of collaborative learning are reflection on the learning process and dialogic inquiry. The dialogue carries a flow of meaning, and discussion involves exchanging of views between participants. In collaborative discussions, participants advocate and defend points of view based on their own observations, interpretations and generalisations (Senge, 1990).

Vygotsky's (1978) sociocultural theory of learning emphasises that human intelligence originates in our society or culture, and individual cognitive gain occurs through interpersonal (interaction with social environment) and intrapersonal (internalisation) ways. The major theme of Vygotsky's theoretical framework is that social interaction plays a fundamental role in the development of cognition. This indicates that learning is more than the accumulation of facts, and it includes a process of enculturation through social interaction and discourse (McLoughlin and Oliver, 2000).

In recent years communication technologies have evolved to support collaborative activities through different forms of computer networks such as the Internet and the World Wide Web. These electronic learning communities may use email, chat, newsgroup, conferencing, forums and bulletin boards to discuss wide ranging topics. These technologies support networked learning communities consisting of students and teachers that may enhance teaching or learning (Jonassen, 2000; Miller and Ewing, 2000; Hollingworth and McLoughlin, 2001).

At the time of writing this paper, all software available for online discussion are text based. Such software allows users to interact with each other by reading one another's text messages. These threaded discussions can occur either in a synchronous mode, chat; or asynchronous mode, list servers (Tiene and Ingram, 2001). Using this type of online, text based discussion, viewers would have to watch the video footage separately before entering the online discussion. Without the facility to attach a comment to a specific location on the video, each discussant has the additional burden of referring back to the actions that occurred at the remembered location of an event on the video.

\section{Conversant Media}

Conversant Media is a server based application software enabling users to engage in collaborative discussion by attaching notes to video footage. 
For some collaborative activities, discourse and simultaneous viewing of video clips are necessary to ensure that the discussants keep in view the video content. Here, the details of specific action in the video are important to the content of the discussion. The recent development of Conversant Media extends learning communities into cyberspace by integrating video viewing and online discussion at the same time. It allows for threaded asynchronous discussion. The current prototype version of the software is LAN based, with a web based version being developed in the future.

The Conversant Media system consists of a media player and some administrative tools. Upon launching the software, the user obtains a default screen pop up as shown in Figure 1. On selecting a movie, the display consists of a media player on the left-hand side of the screen and a commentary frame on the right-hand side of the screen. Each line in the commentary frame represents the title of a comment, which can be clicked open and viewed in the bottom, card display frame. Each video frame has a unique time code, which is inherited by the attached comment. Clicking on a comments title automatically displays the card and brings the video to the attached frame.

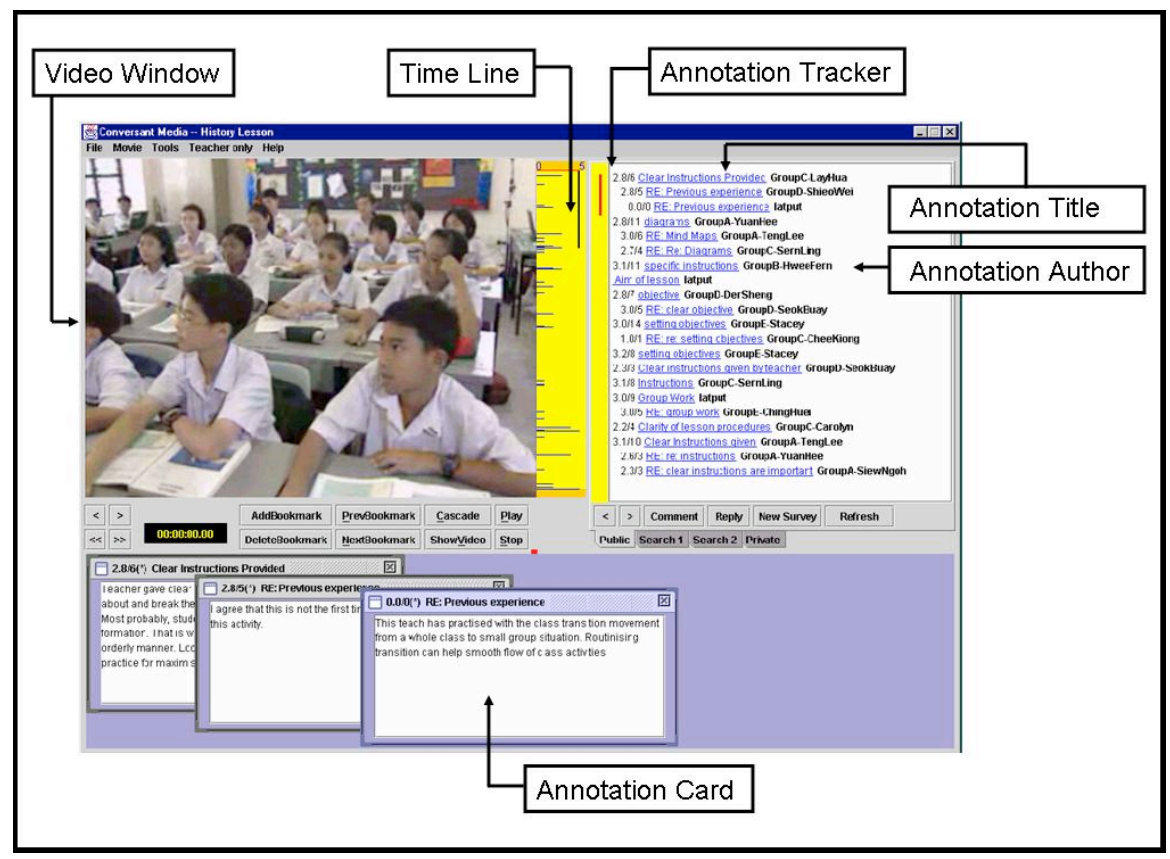

Figure 1: Conversant Media screen 
While viewing a particular segment of a video, if the user is ready to post a comment, the video can be stopped. By using the "Comment" button, a commentary can be created in a dialog box and submitted to the system. The commentary is recorded and the author (commentator's name) is displayed alongside the title of the commentary. In this manner, other users are able to add their own comments or react and reply to other users' comments.

As each annotation is added, a mark is drawn at the corresponding time code position on the timeline for playing the video. Over time, it becomes possible to locate "hot spots" on the video where higher densities of comments are located. The combination of the spatial display of comments attachment locations and the results of peer ratings of the comment allows discussants to keep track of the online discussion. Such an annotation track also allows users to retrieve the records of the commentaries from the database easily. The user can open up to 10 annotation cards that are arranged in cascades in the card display area.

Because the system is designed to encourage thoughtful comments, there is an option for drafting comments before submitting them to the public forum. Here the users create their comments in a "Private Space", which cannot be viewed by other members of the group. When users are ready to share their views, each can then make his or her comments public by publishing them from the private to the public space.

Another feature that attempts to encourage better commentaries is a peer rating system. Every card that is opened by a discussant has to be rated before the user is allowed to proceed. Rating is done on a 1 to 5 scale of overall value and informativeness of the comment. Once the user rates the commentary, he or she can close the window to proceed to the other tasks.

In order to encourage users to find their own commentary voices, there is a feature that constrains discussants to make their initial comments without access to the public debate. Users must add a set number of comments before they can read comments by other users. Once a user has submitted the required number of comments, he or she can log off, and upon logging back in, view his or her own comments and all other comments in the public space.

\section{The investigation}

The Conversant Media software was used in the delivery of the Module: Instructional Strategies and Effective Learning in a teacher education program at the National Institute of Education, Singapore as a way to engage students in reflective analyses of authentic classroom teaching episodes, so 
that they will have a deeper understanding of how the theories are translated to actual practice in classroom situations. This electronic discussion was considered appropriate because students in Singapore do not normally express their views freely and openly in face to face situations. Electronic discussion provides an opportunity for the students to work in private and post their commentary for others to review and comment. Twenty-five students who enrolled for the module participated in the investigation.

\section{Objectives of the study}

The main objective in this pilot study was to explore the opportunity to reflect on instructional issues in authentic classroom episodes and the quality of comments made by trainee teachers through the use of Conversant media software. A secondary objective for this study was to find out the views of trainee teachers pertaining to the use of Conversant Media as a teacher education tool.

\section{Procedure}

The students were introduced to the features of the Conversant Media software and given opportunities for practice use of the different features. The practice consisted of two one-hour sessions. Then they were engaged in three different activities over a period of three weeks. For these activities the students were divided into five groups consisting of five students in each group. The activities were carried out in a computer laboratory.

Three video clips were used in this experiment. The first video showed a teacher using the class project approach to engage the students in the learning process ( 3 minutes and 20 seconds). The second video clip showed a teacher teaching the concept of number sequence using a real life experience - breeding of rabbits ( 5 minutes 25 seconds). The teacher used a presentation approach in the lesson to introduce the topic with the help of a transparency. The third video clip showed a teacher teaching a pre-lab science lesson. The teacher explains and demonstrates the technique of reading the volume of a liquid in a measuring cylinder ( 5 minutes). The pre-lab lesson is in preparation for a laboratory activity to measure the volumes of irregular objects.

Trainee teachers were asked to view the video clip and comment on the various aspects of teaching and classroom management. These included preparation, clarity of instruction, student accountability, appraisal of students' efforts and any other topic related to classroom management. They were also required to read the comments of their peers, rate them, 
and write their responses to the comments. In making their comments they were advised to illustrate with specific principles of good teaching and management used by the teacher. They were also encouraged to give alternative suggestions how the teacher may have handled the event or situation.

\section{Data collection}

To gather information on the use of the tool, the number of comments made by each of the participants was counted and recorded. The quality of the comments was judged by the rating given to each of the comments made by the group members. An average rating of 3.2 on the 5-point scale was considered a good commentary as it corresponds to a B grade in the grading system. The instructor also graded the final two exercises

To obtain the views of the participants about the Conversant Media software and the exercise in which they were involved, a survey form developed by the authors was used to collect information. The survey form contained 40 items and covered the following aspects: video clips, writing comments, reading comments, features of Conversant Media and overall impressions. To each item the participants were required to respond on a 5-point scale strongly disagree to strongly agree.

\section{Results and discussion}

\section{Degree of participation and quality of comments}

Video \#1: The 25 students made 82 comments in all and responded to the comments of their group members 69 times. The mean peer rating on the comments and responses on the 5 -point scale are $2.93(\mathrm{SD}=.37)$ and 2.88 $(\mathrm{SD}=.38)$ respectively. Of the 67 comments and 53 responses that were rated by the participants 12 and 10 attempts received 3.2 and above mean rating respectively (Table 1 ).

Video \# 2: All the students submitted four comments each. The mean peer rating on the comments and responses are $3.17(\mathrm{SD}=.353)$ and $3.11(\mathrm{SD}=$ .34) respectively. 54 of the 100 comments received 3.2 and above mean ratings. They also responded 180 times to the comments of their group members. One or more peers rated 113 of these comments. 34 of these response comments received 3.2 and above mean rating (Table 1).

Video \#3: All the students submitted the required commentary. Each of these commentaries were read and rated by the four other members in the group. The mean peer rating of the commentaries on the 5-point scale is $3.26(\mathrm{SD}=.597)$. Fifteen $(60.0 \%)$ of the commentaries were given a rating of 
3.2 and above. The lecturer also assessed the comments. The mean rating given by the lecturer was $3.22(\mathrm{SD}=.372)$. Also fifteen of the comments received 3.2 and above rating from the lecturer (Table 1).

Table 1: Participation and quality of comments and responses

\begin{tabular}{|l|l|c|c|c|c|}
\hline Video & Type & Total & Rated & $\geq 3.2(\%)$ & Mean rating (SD) \\
\hline$\# 1$ & Comment & 82 & 67 & $12(17.9)$ & $2.93(.37)$ \\
\hline$\# 1$ & Response & 69 & 53 & $10(18.9)$ & $2.88(.38)$ \\
\hline$\# 2$ & Comment & 100 & 100 & $54(54.0)$ & $3.17(.35)$ \\
\hline$\# 2$ & Response & 180 & 113 & $34(30.1)$ & $3.11(.34)$ \\
\hline$\# 3$ & Comment & 25 & 25 & $15(60.0)$ & $3.26(.60)$ \\
\hline$\# 3 *$ & Comment & 25 & 25 & $15(60.0)$ & $3.22(.37)$ \\
\hline * Lecturer's rating
\end{tabular}

From the results discussed above it is clear that commentary skills and students' insight into instructional strategies improved progressively as they participated in the activities. The mean rating for comments in activity \#1 was 2.93 and it increased to 3.17 and 3.26 for activity \#2 and \#3 respectively. Also the percentage of good commentaries has improved over the activities.

A similar system of rating was used by Sorensen and Takle (2002) to assess the quality of students' postings on the web. In their study they found that the quantity of the responses increased with the requirements set for the exercises. Also the quality of the postings improved over the three trials. Macdonald, Weller and Mason (2002) have also reported that evaluation of students' dialogues had a positive effect on the quality of contribution as well as being crucial in the developing online discussion skills. All these suggest that Conversant Media can be a useful tool to help trainee teachers develop the skills of analysing lessons. This will definitely come in handy in their self assessment effort of their teaching.

\section{Participants' views on Conversant Media}

Participants' views were obtained on four aspects, the use of video clips, writing comments, reading comments, and Conversant media features and overall comments. Their responses are tabulated in Tables 2, 3, 4 and 5 respectively.

Table 2 shows the responses on the five items related to use of video clips with Conversant Media software. Responses to the items indicate that students find the viewing of video footage of actual lesson helpful in 
relating theory to practice. They view video clips as a better alternative to case studies. However, they are unhappy with the durations of the video clips, which are only about 5 minutes each. They feel that it does not provide enough information to comment objectively. Some general comments made by the students on the use of video included:

Viewing a real-life classroom scenario in the form of video provides an insight into how instructional strategies can be used to maximise students learning potential, how classroom management can either make or break a lesson.

It enables us to compare different teaching techniques, for us to learn what's good and what not to do.

It will be better if the video clip can be slightly longer and not always end at the climax of the classroom scene.

Table 2: Views related to use of video clips

\begin{tabular}{|c|c|c|c|c|c|c|c|}
\hline \multirow{2}{*}{ No. } & \multirow{2}{*}{ Video clips } & \multicolumn{5}{|c|}{ Frequency $(\%)$} & \multirow{2}{*}{$\begin{array}{c}\text { Mean } \\
\text { SD }\end{array}$} \\
\hline & & 1 & 2 & 3 & 4 & 5 & \\
\hline 1 & $\begin{array}{l}\text { Seeing classroom footage and } \\
\text { talking about classroom events is } \\
\text { an important part in preparing } \\
\text { me to be an effective teacher. }\end{array}$ & & & $\begin{array}{c}4 \\
17.4 \%\end{array}$ & $\begin{array}{c}13 \\
56.5 \%\end{array}$ & $\begin{array}{c}6 \\
26.1 \%\end{array}$ & $\begin{array}{l}4.09 \\
0.67\end{array}$ \\
\hline 2 & $\begin{array}{l}\text { Viewing video clips are better } \\
\text { than analysing case studies of } \\
\text { classroom events to learn about } \\
\text { teaching. }\end{array}$ & & $\begin{array}{c}1 \\
4.3 \%\end{array}$ & $\begin{array}{c}3 \\
13.0 \%\end{array}$ & $\begin{array}{c}10 \\
43.5 \%\end{array}$ & $\begin{array}{c}9 \\
39.1 \%\end{array}$ & $\begin{array}{l}4.17 \\
0.83\end{array}$ \\
\hline 3 & $\begin{array}{l}\text { The video clips provided me with } \\
\text { enough information to interpret } \\
\text { the classroom events. }\end{array}$ & & $\begin{array}{c}7 \\
30.4 \%\end{array}$ & $\begin{array}{c}12 \\
52.2 \%\end{array}$ & $\begin{array}{c}4 \\
17.4 \%\end{array}$ & & $\begin{array}{c}2.87 \\
0.69 \%\end{array}$ \\
\hline 4 & $\begin{array}{l}\text { Seeing the video clips helped me } \\
\text { to see theories translated to } \\
\text { practice in classroom. }\end{array}$ & $\begin{array}{c}1 \\
4.3 \%\end{array}$ & & $\begin{array}{c}8 \\
34.8 \%\end{array}$ & $\begin{array}{c}12 \\
52.2 \%\end{array}$ & $\begin{array}{c}2 \\
8.7 \%\end{array}$ & $\begin{array}{c}3.61 \\
0.84 \%\end{array}$ \\
\hline 5 & $\begin{array}{l}\text { I found it difficult to apply } \\
\text { instruction theories to the specific } \\
\text { classroom events in the video. }\end{array}$ & & $\begin{array}{c}12 \\
52.2 \%\end{array}$ & $\begin{array}{c}6 \\
26.1 \%\end{array}$ & $\begin{array}{c}5 \\
21.7 \%\end{array}$ & & $\begin{array}{c}2.70 \\
0.82 \%\end{array}$ \\
\hline
\end{tabular}

Table 3 shows the response to the four items related to writing comments. All the responses indicate that they have a favourable attitude to the task of writing comments with "writing comments force me to think through what I believed about good teaching" receiving the highest mean rating. From this it can be concluded that this writing comments exercise made the students think critically about teaching. 
Some comments from the students:

There is a free flow of interaction between the trainee teachers. This has enabled more sharing of personal experience in a more relaxed learning environment. Conversant Media is a good tool to train trainee teachers to be expressive. This is especially for trainees who are shy to voice out their views.

Gives more depth into discussions on methods of instruction. Opens up opportunity to observe and exchange views on teaching.

Table 3: Views related to writing comments

\begin{tabular}{|c|c|c|c|c|c|c|c|}
\hline \multirow[b]{2}{*}{ No. } & \multirow[b]{2}{*}{ Writing comments } & \multicolumn{5}{|c|}{ Frequency (\%) } & \multirow{2}{*}{$\begin{array}{c}\text { Mean } \\
\text { SD }\end{array}$} \\
\hline & & 1 & 2 & 3 & 4 & 5 & \\
\hline 6 & $\begin{array}{l}\text { Writing comments helped me } \\
\text { apply pedagogical theories into } \\
\text { actual classroom events. }\end{array}$ & $\begin{array}{c}1 \\
4.3 \%\end{array}$ & $\begin{array}{c}1 \\
4.3 \%\end{array}$ & $\begin{array}{c}10 \\
43.5 \%\end{array}$ & $\begin{array}{c}11 \\
47.8 \%\end{array}$ & & $\begin{array}{l}3.35 \\
0.78\end{array}$ \\
\hline 7 & $\begin{array}{l}\text { CM helped me to think critically } \\
\text { and write about my own ideas } \\
\text { concerning teaching and } \\
\text { management. }\end{array}$ & & & $\begin{array}{c}10 \\
43.5 \%\end{array}$ & $\begin{array}{c}11 \\
47.5 \%\end{array}$ & $\begin{array}{c}2 \\
8.7 \%\end{array}$ & $\begin{array}{l}3.65 \\
0.65\end{array}$ \\
\hline 8 & $\begin{array}{l}\text { Writing comments force me to } \\
\text { think through what I believed } \\
\text { about good teaching. }\end{array}$ & & & $\begin{array}{c}5 \\
21.7 \%\end{array}$ & $\begin{array}{c}15 \\
65.2 \%\end{array}$ & $\begin{array}{c}3 \\
13.0\end{array}$ & $\begin{array}{c}3.91 \\
.60\end{array}$ \\
\hline 9 & $\begin{array}{l}\text { CM helped me to apply } \\
\text { pedagogical theories into actual } \\
\text { classroom events. }\end{array}$ & $\begin{array}{c}1 \\
4.3 \%\end{array}$ & & $\begin{array}{c}14 \\
60.9 \%\end{array}$ & $\begin{array}{c}8 \\
34.8 \%\end{array}$ & & $\begin{array}{l}3.26 \\
0.69\end{array}$ \\
\hline
\end{tabular}

Table 4 shows the responses to the nine items related to reading peer comments. Here again we see positive views expressed about reading the comments of the peers. Even the negatively worded item shows that the participants value reading the comments of their peers. The opportunity to compare views and see alternative points of view is highly valued. A general comment related to this aspect:

Conversant media provides the trainee teachers with a medium to converse and criticise each other's comments.

Table 5 displays the response patterns to the twelve items related to overall impressions about Conversant media. The response patterns indicate that the trainee teacher enjoyed the exercise and did not feel threatened or anxious about making comments on the lessons and getting feedback from their peers. They also felt that Conversant Media can provide a means to create a community of learners who benefit from each other by sharing their views. The most appreciated aspect of Conversant Media is the opportunity it provides for those who are too shy to express their views directly, to do so through this electronic medium. 
Table 4: Views related to reading comments

\begin{tabular}{|c|c|c|c|c|c|c|c|}
\hline \multirow{2}{*}{ No. } & \multirow{2}{*}{ Reading comments } & \multicolumn{5}{|c|}{ Frequency $(\%)$} & \multirow{2}{*}{$\begin{array}{c}\text { Mean } \\
\text { SD }\end{array}$} \\
\hline & & 1 & 2 & 3 & 4 & 5 & \\
\hline 10 & $\begin{array}{l}\text { My peer's opinion broadened } \\
\text { my perspective of teaching } \\
\text { and class management. }\end{array}$ & & $\begin{array}{c}1 \\
4.3 \%\end{array}$ & $\begin{array}{c}6 \\
26.1 \% \\
\end{array}$ & $\begin{array}{c}15 \\
65.2 \%\end{array}$ & $\begin{array}{c}1 \\
4.3 \%\end{array}$ & $\begin{array}{l}3.70 \\
0.63\end{array}$ \\
\hline 11 & $\begin{array}{l}\text { My classmates' comments had } \\
\text { little value to me. }\end{array}$ & $\begin{array}{c}4 \\
17.4 \%\end{array}$ & $\begin{array}{c}17 \\
73.9 \%\end{array}$ & $\begin{array}{c}1 \\
4.3 \%\end{array}$ & $\begin{array}{c}1 \\
4.3 \% \\
\end{array}$ & & $\begin{array}{l}1.96 \\
0.64\end{array}$ \\
\hline 12 & $\begin{array}{l}\text { Reading my classmates' } \\
\text { comments helped me how to } \\
\text { interpret classroom events }\end{array}$ & & $\begin{array}{c}1 \\
4.3 \%\end{array}$ & $\begin{array}{c}5 \\
21.7 \%\end{array}$ & $\begin{array}{c}17 \\
73.9 \%\end{array}$ & & $\begin{array}{l}3.70 \\
0.56\end{array}$ \\
\hline 13 & $\begin{array}{l}\text { Reading my peers' comments } \\
\text { about the classroom events } \\
\text { helped me understand better } \\
\text { the theories discussed in class. }\end{array}$ & $\begin{array}{c}1 \\
4.3 \%\end{array}$ & $\begin{array}{c}1 \\
4.3 \%\end{array}$ & $\begin{array}{c}8 \\
34.8 \%\end{array}$ & $\begin{array}{c}11 \\
47.8 \%\end{array}$ & $\begin{array}{c}2 \\
8.7 \%\end{array}$ & $\begin{array}{l}3.52 \\
0.90\end{array}$ \\
\hline 14 & $\begin{array}{l}\text { Responses from my peers on } \\
\text { my comments helped me see } \\
\text { the alternative point of view. }\end{array}$ & & & $\begin{array}{c}5 \\
21.7 \%\end{array}$ & $\begin{array}{c}13 \\
56.5 \%\end{array}$ & $\begin{array}{c}5 \\
21.7 \%\end{array}$ & $\begin{array}{l}4.00 \\
0.67\end{array}$ \\
\hline 15 & $\begin{array}{l}\text { Reading my peers' comments } \\
\text { made me write better } \\
\text { comments. }\end{array}$ & & $\begin{array}{c}4 \\
17.4 \%\end{array}$ & $\begin{array}{c}10 \\
43.5 \% \\
\end{array}$ & $\begin{array}{c}7 \\
30.4 \%\end{array}$ & $\begin{array}{c}2 \\
8.7 \%\end{array}$ & $\begin{array}{l}3.30 \\
0.88\end{array}$ \\
\hline 16 & $\begin{array}{l}\text { I came to know my } \\
\text { classmates' opinions on } \\
\text { classroom teaching much } \\
\text { better with CM than in a } \\
\text { normal class situation. }\end{array}$ & & $\begin{array}{c}3 \\
13.0 \%\end{array}$ & $\begin{array}{c}7 \\
30.4 \%\end{array}$ & $\begin{array}{c}11 \\
47.8 \%\end{array}$ & $\begin{array}{c}2 \\
8.7 \%\end{array}$ & $\begin{array}{l}3.52 \\
0.85\end{array}$ \\
\hline 17 & $\begin{array}{l}\text { Reading comments helped me } \\
\text { to compare my classmates' } \\
\text { way of viewing the events to } \\
\text { my own. }\end{array}$ & & & $\begin{array}{c}5 \\
21.7 \%\end{array}$ & $\begin{array}{c}10 \\
43.5 \%\end{array}$ & $\begin{array}{c}8 \\
34.8 \%\end{array}$ & $\begin{array}{l}4.13 \\
0.71\end{array}$ \\
\hline 18 & $\begin{array}{l}\text { My peers' view provoked } \\
\text { critical self-reflection on my } \\
\text { view. }\end{array}$ & & & $\begin{array}{c}13 \\
56.5 \%\end{array}$ & $\begin{array}{c}9 \\
39.1 \%\end{array}$ & $\begin{array}{c}1 \\
4.3 \%\end{array}$ & $\begin{array}{l}3.48 \\
0.59\end{array}$ \\
\hline
\end{tabular}

Some general comments from the students:

It is quite fun watching the video and commenting on the video. Because students do not have to speak, shy students are able to voice their opinion. For students who are slow, they can take their time to finish up their without delaying the rest of the class.

I think it is an extremely good tool for teacher trainees to 'experience' actual teaching lessons and to see the pros and cons of a teacher's method of teaching. 
Table 5: Students overall impressions

\begin{tabular}{|c|c|c|c|c|c|c|c|}
\hline \multirow{2}{*}{ No. } & \multirow{2}{*}{ Overall impression } & \multicolumn{5}{|c|}{ Frequency $(\%)$} & \multirow{2}{*}{$\begin{array}{l}\text { Mean } \\
\text { SD }\end{array}$} \\
\hline & & 1 & 2 & 3 & 4 & 5 & \\
\hline 19 & $\begin{array}{l}\text { Conversant media is fun to } \\
\text { use. }\end{array}$ & & $\begin{array}{c}2 \\
8.7 \%\end{array}$ & $\begin{array}{c}12 \\
52.7 \%\end{array}$ & $\begin{array}{c}7 \\
30.4 \%\end{array}$ & $\begin{array}{c}2 \\
8.7 \%\end{array}$ & $\begin{array}{l}3.39 \\
0.78\end{array}$ \\
\hline 20 & $\begin{array}{l}\text { I enjoyed the opportunity to } \\
\text { exchange views with my } \\
\text { group members. }\end{array}$ & $\begin{array}{c}1 \\
4.3 \%\end{array}$ & & $\begin{array}{c}7 \\
30.4 \%\end{array}$ & $\begin{array}{c}11 \\
47.8 \%\end{array}$ & $\begin{array}{c}4 \\
17.4 \%\end{array}$ & $\begin{array}{l}3.74 \\
0.92\end{array}$ \\
\hline 21 & $\begin{array}{l}\text { I had no major problems in } \\
\text { using the different features in } \\
\text { Conversant media. }\end{array}$ & & $\begin{array}{l}2 \\
8.7 \%\end{array}$ & $\begin{array}{c}11 \\
47.8 \%\end{array}$ & $\begin{array}{c}8 \\
34.8 \%\end{array}$ & $\begin{array}{c}2 \\
8.7 \%\end{array}$ & $\begin{array}{l}3.43 \\
0.79\end{array}$ \\
\hline 22 & $\begin{array}{l}\text { CM provided a non- } \\
\text { threatening environment to } \\
\text { express my views. }\end{array}$ & & & $\begin{array}{c}2 \\
8.7 \%\end{array}$ & $\begin{array}{c}12 \\
52.2 \%\end{array}$ & $\begin{array}{c}9 \\
39.1 \%\end{array}$ & $\begin{array}{l}4.30 \\
0.63\end{array}$ \\
\hline 23 & $\begin{array}{l}\text { CM helped me to think of } \\
\text { other students' opinion on } \\
\text { classroom events. }\end{array}$ & & & $\begin{array}{c}7 \\
30.4 \%\end{array}$ & $\begin{array}{c}13 \\
56.5 \%\end{array}$ & $\begin{array}{c}3 \\
13.0 \%\end{array}$ & $\begin{array}{l}3.83 \\
0.65\end{array}$ \\
\hline 24 & $\begin{array}{l}\text { The exchange of views was } \\
\text { cordial and pleasant. }\end{array}$ & & $\begin{array}{c}1 \\
4.3 \% \\
\end{array}$ & $\begin{array}{c}6 \\
26.1 \% \\
\end{array}$ & $\begin{array}{c}14 \\
60.9 \% \\
\end{array}$ & $\begin{array}{c}2 \\
8.7 \%\end{array}$ & $\begin{array}{l}3.74 \\
0.69\end{array}$ \\
\hline 25 & $\begin{array}{l}\text { Conversant media can help } \\
\text { create a community of } \\
\text { learners. }\end{array}$ & & $\begin{array}{c}1 \\
4.3 \%\end{array}$ & $\begin{array}{c}7 \\
30.4 \%\end{array}$ & $\begin{array}{c}14 \\
60.9 \%\end{array}$ & $\begin{array}{c}1 \\
4.3 \%\end{array}$ & $\begin{array}{l}3.65 \\
0.65\end{array}$ \\
\hline 26 & $\begin{array}{l}\text { Conversant media provides a } \\
\text { mean to those who are shy to } \\
\text { express their views. }\end{array}$ & & & $\begin{array}{c}3 \\
13.0 \%\end{array}$ & $\begin{array}{c}8 \\
34.8 \%\end{array}$ & $\begin{array}{c}12 \\
52.2 \%\end{array}$ & $\begin{array}{l}4.39 \\
0.72\end{array}$ \\
\hline 27 & $\begin{array}{l}\mathrm{CM} \text { helped me to learn } \\
\text { commentary skill. }\end{array}$ & & $\begin{array}{c}2 \\
8.7 \%\end{array}$ & $\begin{array}{c}10 \\
43.5 \%\end{array}$ & $\begin{array}{c}10 \\
43.5 \%\end{array}$ & $\begin{array}{c}1 \\
4.3 \%\end{array}$ & $\begin{array}{l}3.43 \\
0.73\end{array}$ \\
\hline 28 & $\begin{array}{l}\text { A commentary culture can be } \\
\text { developed among tertiary } \\
\text { education students through } \\
\text { the use of CM. }\end{array}$ & & & $\begin{array}{c}10 \\
43.5 \%\end{array}$ & $\begin{array}{c}10 \\
43.5 \%\end{array}$ & $\begin{array}{c}3 \\
13.0 \%\end{array}$ & $\begin{array}{l}3.70 \\
0.70\end{array}$ \\
\hline 29 & $\begin{array}{l}\text { I feel anxious about people } \\
\text { not liking my comments }\end{array}$ & $\begin{array}{c}4 \\
17.4 \%\end{array}$ & $\begin{array}{c}11 \\
47.8 \%\end{array}$ & $\begin{array}{c}5 \\
21.7 \%\end{array}$ & $\begin{array}{c}3 \\
13.0 \%\end{array}$ & & $\begin{array}{l}2.30 \\
0.93\end{array}$ \\
\hline 30 & $\begin{array}{l}\text { I prefer CM to get my } \\
\text { classmates' views than just } \\
\text { watching the video and } \\
\text { talking about it in class. }\end{array}$ & & $\begin{array}{c}2 \\
8.7 \%\end{array}$ & $\begin{array}{c}6 \\
26.1 \%\end{array}$ & $\begin{array}{c}9 \\
39.1 \%\end{array}$ & $\begin{array}{c}6 \\
26.1 \%\end{array}$ & $\begin{array}{l}3.83 \\
0.94\end{array}$ \\
\hline
\end{tabular}




\section{Conclusion}

The development of Conversant Media represents an exciting new step in the provision of collaborative learning. With a web based version in the future, interaction could be further enhanced on an anytime, anywhere basis. By presenting challenging video based materials, educators will be able to promote group dynamics and collaboration among students. Learning as a result of interaction will be enriched and facilitate higher order thinking and problem solving skills.

The results of this trial indicate that students have benefited from their use of the software in the delivery of this course. Their commentary skills have improved over the three activities in which they were engaged. The quality and quantity of good comments increased over the three activities. Even the lecturer's rating of the comments indicates that the trainee teachers have developed the ability to analyse teaching episodes and make quality comments that reflect an understanding of the teaching-learning process in the actual classroom. This seems to suggest that Conversant Media could be used to help students develop commentary skills as well as promote a critical view of instructional strategies, which was the purpose of the activities.

Students who are new to online collaboration may take time before they develop the various skills need to feel comfortable interacting in this medium. Conversant Media may be useful as a way of building skills for online collaboration in an incremental way, and raising awareness of the benefits of collaborative learning. Rating of the postings may be another way for encouraging not only participation but also contributing to the knowledge building process through collaborative learning.

With respect to the perceptions of the trainee teachers using Conversant Media, in general they are positive of the different aspects of online discussion. They are of the view that viewing classroom video footage and reflecting on the approaches can be an important means in training to be teachers. They feel that this method is better than discussing case studies or content of video clips. Writing comments on the lesson forces them to think and see the relationship between theory and practice. Reading the feedback comment of peers is also highly valued by the students. They feel that it provides them the opportunity to compare views and see alternative points of view. This is in line with the principle of collaborative learning where the process of learning is viewed to be a fundamentally social phenomenon. 
On the whole it can be said that Conversant Media is versatile software to help students participate actively in the learning process. This tool can be specifically useful in teacher education as an alternative means to school visits to see the action in the classroom and conduct discussions. Through this software it is possible to bring the classroom to the computer laboratories of the teacher education institutions and engage the students in powerful learning activities. The current prototype version of the software is LAN based and only allows use in networked computer laboratories. A web based version of the software is being developed and this will enable student access from home machines. In other applications, it was found that with dialup connections, streaming video attains a reasonable frame rate.

Numerous studies have identified specific characteristics that distinguish one culture to another. Anthropological approaches to cultural differences suggest that Asians tend to display a sense of respect for the other party, believe in giving an indirect response, and find it difficult to show displeasure (Scarborough, 1998). Expressions of open and frank opinions are rarely seen in the social context. Stigler and Hiebert (1992) pointed out the importance of cultural differences in learning interactions between teachers and students in different cultures. This software can be a useful tool particularly in this context where students are reluctant to express their views in the class and face to face situation.

Trainee teachers most often complain that the teacher education programs are too theoretical. Sorensen (1997) points out that the process of knowledge building involves mutual exploration of issues, mutual exploration of arguments, mutual questioning of positions and weaving of ideas. Conversant Media can provide the means to help them see theory in action in the classroom even before the set foot in school to teach. It may be appropriate to end with a student's verdict on Conversant Media:

A useful tool in teacher education. Allows trainee teachers to view actual classroom situations and able to relate theory to practice.

\section{Acknowledgement}

The authors would like to thank the Laboratories for Information Technology, Singapore for the Conversant Media software used in this study. 


\section{References}

Hollingworth, R. \& McLoughlin, C. (2001). Developing science students' metacognitive problem solving skills online. Australian Journal of Educational Technology, 17(1), 50-63.

http: / / www.ascilite.org.au / ajet / ajet17 / hollingworth.html

Jonassen, D., Peck \& Wilson (1999). Learning with technology: A constructivist perspective. New Jersey: Prentice-Hall.

Jonassen, D. (2000). Computers as mindtools for schools. New Jersey: Prentice-Hall.

Kearsley, G. (2000). Online education: Learning and teaching in Cyberspace. Belmont: California: Wadsworth.

Lewin, K. (1943). Forces behind food habits and methods of change. Bulletin of the National Research Council, 108, 35-65.

Macdonald, J., Weller, M. \& Mason, R. (2002). Meeting the assessment demands of network courses. International Journal on E-Learning, 1(1), 9-18.

McLoughlin, C. \& Oliver, R. (2000). Designing learning environments for cultural inclusivity: A case study of indigenous online learning at tertiary level. Australian Journal of Educational Technology, 16(1), 58-72. http: / / www.ascilite.org.au/ajet/ajet16/mcloughlin.html

Miller, D. \& Ewing, J. (2000). Beyond knowledge transmission? Computersupported learning in teacher education: Some benefits in terms of stress, control and self-belief. Journal of Information Technology for Teacher Education, 9(3), 363-376.

Palloff, R. M. \& Pratt, K. (1999). Building learning communities in Cyberspace: Effective strategies for the online classroom. San Francisco: Jossey-Bass.

Palloff, R. M. \& Pratt, K. (2001). Lessons from the Cyberspace classroom: The realities of online teaching. San Francisco: Jossey-Bass.

Senge, P. (1990). The fifth discipline: The art and practice of the learning organization. New York: Doubleday Currency.

Sorensen, E. K. (1997). Learning in virtual contexts: Navigation, interaction and collaboration. Cited in Sorensen \& Takle (2002), Collaborative knowledge building in web-based learning: Assessing the quality of dialogue. International Journal on E-Learning, 1(1), 33-42.

Sorensen, E. K., \& Takle, E. S. (2002). Collaborative knowledge building in webbased learning: Assessing the quality of dialogue. International Journal on ELearning, 1(1), 33-42. 
Scarborough, J. (1998). The origin of cultural differences and their impact on management. Westport, Connecticut: Quorum Books.

Stigler, J. W. \& Hiebert, J. (1999). The teaching gap. New York: Simon \& Schuster.

Tiene, D. \& Ingram, A. (2001). Exploring current issues in educational technology. Boston: McGraw-Hill.

Vygotsky, L. S. (1978). Mind in Society. Cambridge, MA: Harvard University Press.

Dr Myint Swe Khine

Associate Professor, Instructional Science Academic Group

National Institute of Education

Nanyang Technological University, Singapore 637616

Email: mskhine@nie.edu.sg

http: / / eduweb.nie.edu.sg/is/

Dr Atputhasamy Lourdusamy

Senior Fellow, Instructional Science Academic Group

National Institute of Education

Nanyang Technological University, Singapore 637616

Email: latput@nie.edu.sg

http: / / eduweb.nie.edu.sg/is/ 